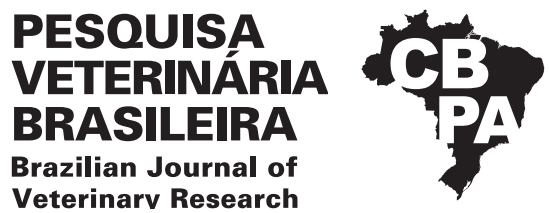

Pesq. Vet. Bras. 40(5):381-384, May 2020 DOI: 10.1590/1678-5150-PVB- 6311

Original Article Veterinarv Research

ISSN 0100-736X (Print) Livestock Diseases

ISSN 1678-5150 (Online)

\title{
ELISA of amyloid A in paired bronchoalveolar lavage fluid and serum samples of healthy horses ${ }^{1}$
}

\author{
Paula Alessandra Di Filippo²* (D), Luiza M.F. Ribeiro², Marcos A.D. Meireles², \\ Saulo T. Lannes ${ }^{2}$, Luciana. M. Mello ${ }^{2}$, Francielli P. Gobbi ${ }^{2}$, Luiz F.A. Toledo ${ }^{3}$ \\ and Daniel A.B. Lessa ${ }^{3}$
}

\begin{abstract}
Di Filippo P.A., Ribeiro L.M.F., Meireles M.A.D., Lannes S.T., Mello L.M., Gobbi F.P., Toledo L.F.A. \& Lessa D.A.B. 2020. ELISA of amyloid A in paired bronchoalveolar lavage fluid and serum samples of healthy horses. Pesquisa Veterinária Brasileira 40(5):381-384. Laboratório de Clínicas e Cirurgia Veterinária, Centro de Ciências e Tecnologias Agropecuárias, Universidade Estadual do Norte Fluminense "Darcy Ribeiro", Av. Alberto Lamego 2000, Campos dos Goytacazes, RJ 28013-602, Brazil. E-mail: pdf@uenf.br

Pulmonary disorders are common in horses, and treatment efficiency depends on an adequate diagnosis. Amyloid $\mathrm{A}$ is the most sensitive indicator of pathology in horses. The objective of this study was to establish the concentration of amyloid A of bronchoalveolar lavage fluid (BALF) in healthy horses. Health condition of horses was considered normal based on physical examination, complete blood count, biochemical parameters, and BALF cytology. Blood and BALF were collected from thirty adult female horses. Amyloid A concentrations in serum and BALF were measured using commercial ELISA tests. Amyloid A was detected in serum (mean $\pm \mathrm{SD}=3.71 \pm 2.51$ ) and BALF (mean $\pm \mathrm{SD}=0.000745 \pm 0.000785$ ) of all horses . In conclusion, SAA can also be measured in bronchoalveolar fluid, affording early detection of respiratory infections or inflammatory conditions.
\end{abstract}

INDEX TERMS: ELISA, amyloid A, bronchoalveolar lavage, serum, healthy horses, acute phase protein, biomarker, lung, inflammation, horses.

RESUMO.- [Detecção de amilóide A no lavado broncoalveolar de equinos hígidos]. Distúrbios pulmonares são comuns nos cavalos e a eficiência do tratamento depende de um diagnóstico adequado e precoce. A amilóide A é um biomarcador sensível na deteccção de patologias inflamatórias e infecciososa em cavalos. 0 objetivo deste estudo foi estabelecer a concentração de amilóide A no líquido broncoalveolar (LBA) em cavalos saudáveis. Os cavalos foram considerados saudaveis baseado nos achados de normalidade do exame físico, hemograma, parâmetros bioquímicos e citologia do LBA. Sangue e LBA foram coletados de 30 fêmeas equinas adultas. Os níveis de Amilóide A no soro e no LBA foram mensurados por meio do

\footnotetext{
${ }^{1}$ Received on September 5, 2019.

Accepted for publication on December 7, 2019.

${ }^{2}$ Laboratório de Clínicas e Cirurgia Veterinária (LCCA), Centro de Ciências e Tecnologias Agropecuárias (CCTA), Universidade Estadual do Norte Fluminense "Darcy Ribeiro" (UENF), Av. Alberto Lamego 2000, Parque Califórnia, Campos dos Goytacazes, RJ 28013-602, Brazil. E-mails: f.feitosaribeiro@gmail.com, marcosadmeireles@yahoo.com.br, stlannes@yahoo.com.br, luvetmello@ gmail.com, franci_gobbi@hotmail.com; *Corresponding author:pdf@uenf.br

${ }^{3}$ Universidade Federal Fluminense (UFF), Rua Vital Brasil Filho 64, Niterói, RJ 24230-340, Brazil. E-mails: Ifatoledo@id.uff.br, lessadab@gmail.com
}

teste de ELISA. A amilóide A foi detectada no soro (média \pm DP $=3,71 \pm 2,51$ ) e no LBA (média $\pm \mathrm{DP}=0,000745 \pm 0,000785$ ) $\mathrm{de}$ todos os animais. Conclui-se que a amilóide $\mathrm{A}$ também pode ser mensurada no LBA, auxiliando no diagnóstico precoce de processos inflamatórios e infecciosos pulmonares.

TERMOS DE INDEXAÇÃO: Amilóide A, lavado broncoalveolar, equinos hígidos, proteínas de fase aguda, biomarcadores, pulmões, inflamação, cavalos.

\section{INTRODUCTION}

Inflammatory airway disease (IAD) is one of the most important pulmonary disorders in athletic horses. This syndrome is characterized by cough, decreased performance, and delayed recovery after exercise with normal respiratory effort at rest (Couëtil et al. 2007). Inflammation is a complex process, and early diagnosis is essential to devise and implement an effective treatment plan (Crisman et al. 2008). Markers of inflammatory disease have recently attracted attention in the scientific community. In equine medicine, for example, the usefulness of clinically applied inflammatory markers such as serum amyloid A protein (SAA) has been reported 
in previous studies (Hultén \& Demmers 2002, Jacobsen \& Andersen 2007).

Equine SAA increases rapidly and considerably (more than 100 times). However, this increase does not afford the exact diagnosis; rather, it only broadly signals the presence of a pathology (Hultén et al. 1999, Cywinska et al. 2013). High serum SAA concentration was found in horses with inflammatory airway disease (Viner et al. 2017), heaves (Lavoie-Lamoureux et al. 2012), infectious respiratory diseases (equine influenza virus, equine herpesvirus- 4 and Streptococcus equi subspecies equi), and bacterial pneumonia (Hobo et al. 2007).

The liver is the main site of SAA, but several extrahepatic isoforms of SAA have been demonstrated in horses (McDonald et al. 2001, Jacobsen et al. 2006a, Christoffersen et al. 2010). The extrahepatic production of SAA works as a local and immediate defense against tissue injury from inflammatory challenges until a systemic/hepatic response is elicited (Uhlar and Whitehead 1999). Studies describing the detection of amyloid A in bronchoalveolar lavage fluid are scarce. Therefore, the aim of this study was to establish the pattern of amyloid A concentrations in bronchoalveolar lavage fluid (BALF) obtained from healthy horses using ELISA tests.

\section{MATERIALS AND METHODS}

This study was approved by the Ethics Committee on Animal Experiments of "Universidade Estadual do Norte Fluminense Darcy Ribeiro" (CEUA-UENF), under protocol number 901139.

Thirty crossbreed female horses whose ages ranged from 5-7 years and body weight between 400 and $425 \mathrm{~kg}$ were studied. All horses were kept in semi-confinement, in $10-\mathrm{m}^{2}$ stall boxes with cement floor and no bedding. Feeding included 3 to $4 \mathrm{~kg} /$ day of commercial horse concentrate per animal, containing $12 \%$ total protein, $4 \mathrm{~kg}$ of Coast-Cross grass hay/animal per day, mineral salt, and water ad libitum. The animals were dewormed every four months and vaccinated against influenza, tetanus, rabies, equine adenitis, and leptospirosis. The horses had no history of respiratory disease or medical treatment during the 30 days preceding data collection.

The animals included were considered healthy after a routine physical evaluation, pulmonary auscultation and percussion, endoscopy examination, complete blood count, and cytological analysis of bronchoalveolar lavage fluid according to the values described by Viscardi et al. (2015), and Couëtil et al. (2016).

Bronchoalveolar lavage was performed in the standing horse using a special silicone BAL catheter (BIVONA ${ }^{\circledR}$ ), under mild sedation (detomidine, $0.5 \mathrm{mg} / \mathrm{kg}$ bwt i.v). The catheter was advanced via the trachea until being wedged in a distal bronchus. The cuff was then filled with $8 \mathrm{~mL}$ air and $250 \mathrm{~mL}$ of warm $\left(37^{\circ} \mathrm{C}\right)$ sterile $0.9 \%$ saline (divided into 3 boluses) were sequentially instilled and immediately aspired. Samples were considered adequate if at least $40 \%$ of the infused liquid was recovered and when surfactant and turbidity were observed. After collection, the aliquots of BALF were pooled and macroscopically examined to evaluate the color, transparency, and the presence of flocculent debris. Flocculent samples were filtrated through two layers of gauze to remove excess mucus strands and other debris.

The samples were maintained at $-4^{\circ} \mathrm{C}$ in sterile test tubes for cytological processing and at $-20^{\circ} \mathrm{C}$ for SAA determination. Within $1 \mathrm{~h}$ of collection the samples used in the cytological analysis were cytocentrifuged (Cytopro 7620, Wescor ${ }^{\circledR}$ ) at $110 \mathrm{~g}$ for $5 \mathrm{~min}$ and stained with May-Grunwald, Giemsa $\left(\right.$ Merck $\left.^{\circledR}\right)$. Differential cell counts were performed by counting 500 cells, excluding epithelial cells.
Venous blood samples $(7 \mathrm{~mL})$ were collected form the jugular vein with a Vacutainer (BD) into plain tubes. Samples were centrifuged $(1500 \mathrm{~g}, 10 \mathrm{~min})$ and the serum separated and stored at $-20^{\circ} \mathrm{C}$ for subsequent SAA analysis.

The amyloid A levels in paired BALF and serum samples were measured using the enzyme linked immunosorbent assay (ELISA, PHASE $^{\mathrm{TM}}$ SAA Assay, Tridelta Ltd., Ireland) previously validated for use in equine studies (Coutinho da Silva et al. 2014, Leclere et al. 2015, Turło et al. 2015a, 2015b). Samples were evaluated in duplicate and only serum samples were diluted (1:2000), and the results appropriately recalculated. Data are expressed as $\mathrm{mg} / \mathrm{mL}$.

The data obtained were submitted to descriptive analysis, and means, maximum and minimum values were determined using the SAS statistical program.

\section{RESULTS AND DISCUSSION}

The results are summarized in Table 1 and 2. BALF cytology profile of the healthy horses was characterized by the prevalence of alveolar macrophages and lymphocytes, followed by neutrophils, mast cells, eosinophils and a small percentage of epithelial cells. These results are similar to the findings described by Viscardi et al. (2015), Wysocka \& Kluciński (2015) and in a recent Consensus Statements of the American College of Veterinary Internal Medicine (Couëtil et al. 2016).

The SAA concentrations in serum of healthy horses were similar to the values described by other authors using the same methodology (Coutinho da Silva et al. 2014, Turło et al. 2015a, 2015b). Increased in SAA concentrations were found in horses with infectious and noninfectious respiratory diseases (Viner et al. 2017). SAA values from horses with Streptococcus equi subsp. equi were significantly higher, when compared to horses with viral infections (EIV/EHV-4). However, due to the high similarity in SAA values between these two groups it was not possible to differentiate them based solely on SAA concentrations. For Viner et al. (2017), SAA may assist in the differentiation between respiratory infections and non-infectious inflammatory respiratory diseases presenting similar clinical signs.

Increased in SAA concentrations have been observed in horses infected with influenza virus (Hultén et al. 1999), Streptococcus zooepidemicus (Hobo et al. 2007), and in foals with Rhodococcus equi pneumonia (Hultén \& Demmers 2002). In a study with horses with influenza virus infection, Hultén et al. (1999) observed that SAA reacts more rapidly than fibrinogen. The authors concluded that measurement of SAA is useful as a method of anticipating the clinical condition in

Table 1. Percentage of cells recovered from bronchoalveolar lavage fluid in healthy horses Percentage of cells

\begin{tabular}{cccccc}
\hline Macrophages Lymphocytes & Neutrophils & Eosinophils & Mast cell & $\begin{array}{c}\text { Epithelial } \\
\text { cells }\end{array}$ \\
\hline $43.80 \pm 17.01$ & $36.4 \pm 21.54$ & $4.6 \pm 3.80$ & $1.8 \pm 0.84$ & $1.60 \pm 0.84$ & $0.70 \pm 1.90$
\end{tabular}

Table 2. Amyloid A concentration in healthy horses

\begin{tabular}{cccccc}
\hline \multicolumn{5}{c}{ Amyloid A concentration $(\mathrm{mg} / \mathrm{mL})$} \\
\hline Serum & BALF \\
\hline Median & Minimum & Maximum & Median & Minimum & Maximum \\
3.71 & 0.21 & 9.43 & 0.000745 & 0.000054 & 0.002518
\end{tabular}

BALF = bronchoalveolar lavage fluid. 
equine influenza virus infection. On the other hand, a study developed with the objective of evaluating the usefulness of weekly tests of serum amyloid A (SAA) and plasma fibrinogen concentrations in foals to achieve early diagnosis of $R$. equi pneumonia prior to the onset of clinical signs, demonstrated that while SAA concentrations may rise during clinically manifest $R$. equi pneumonia, SAA does not represent a reliable early marker of Rhodococcosis when plasma concentrations are tested once a week. At the same time, this study raises the possibility that plasma fibrinogen monitoring starting at 1 week of age and repeated on a weekly basis, could serve as a screening test allowing clinicians to identify foals as suspected of $R$. equi infection (Passamonti et al. 2015). The SAA response is dependent on the nature and intensity of the inflammatory stimulus (Hultén \& Demmers 2002, Jacobsen \& Andersen 2007, Crisman et al. 2008), justifying the diferente results described above. According to Jacobsen \& Andersen (2007), after having excluded the existence of coexisting noxious stimuli, plasma SAA concentrations may also serve as a good indicator of disease status, reflecting clinical improvement or deterioration as well as the quality of the response to treatment.

Horses with recurrent airway obstruction (RAO, or heaves) also had increased concentrations of serum amyloid A (Lavoie-Lamoureux et al. 2012). Also, SAA concentrations were 3.5 times higher in horses with inflammatory airway disease (IAD) when compared to controls horses (Bullone et al. 2015). In other words, it has been suggested that SAA increases proportionately to the extent of tissue damage. However, another study revealed that there was no difference in SAA concentration between exercise-intolerant horses with and without IAD (Leclere et al. 2015). The results of that study were associated with the small number of samples used, not with the ineffectiveness of SAA as a blood marker of airway inflammation. Importantly, SAA is considered a "major" acute phase protein, with a very rapid (24-48 hours) and pronounced ( 10 -fold or over) increase with inflammation (Crisman et al. 2008).

Although the main source of acute phase proteins is the liver, extrahepatic SAA isoforms may also be produced (Upragarin et al. 2005, Christoffersen et al. 2010). In horses, SAA protein has been detected in colostrum (McDonald et al. 2001), synovial fluid (Jacobsen et al. 2006a), and in the endometrium of mares with uterine Escherichia coli infection (Christoffersen et al. 2010). Yet, the present study is the first report on lung SAA in healthy horses.

The local functions of SAA protein have not yet been fully understood, but it has been suggested that SAA is part of the innate host response against the invasion of microorganisms or assist in maintenance of tissue functions in organs that communicate with the environment, such as the lungs (Urieli-Shoval et al. 1998). The production of this protein in the mammary gland may have protective effects in the neonatal intestine (Duggan et al. 2008). In joints, SAA may contribute to inflammation and cartilage destruction, acting as a chemoattractant for leukocytes, inducing cyclooxygenase metabolite formation, and regulating metalloproteinase activity (O'Hara et al. 2004). Thus, the syntheses of SAA in joints suggests an important pathophysiological role in inflammatory arthritis in horses (Jacobsen et al. 2006b). In addition, the local determination of SAA levels improves diagnosis accuracy, because it provides information on the inflammatory/infectious status of the particular organ of interest (Jacobsen \& Andersen 2007). Early detection of respiratory disease in horses is crucial, and SAA should be assessed in that context. Depending on the nature of the inflammatory stimulus, SAA values have been reported to start increasing by 4 to $12 \mathrm{~h}$ following acute inflammation, reach peak values within $48 \mathrm{~h}$ and return to baseline concentrations between 3 days and 3 weeks (Hultén \& Demmers 2002, Jacobsen \& Andersen 2007, Crisman et al. 2008). However, in healthy animals it is common to obtain low or undetectable SAA values (Crisman et al. 2008), such as those observed in BALF of the animals in this study (Table 2).

\section{CONCLUSIONS}

The determination of serum amyloid A protein (SAA) in bronchoalveolar lavage fluid (BALF) is possible, therefore, healthy horses have a low SAA concentration in BALF.

The knowledge of SAA values in healthy horses may help in the interpretation of samples from diseased animals facilitating early detection of airway disease in horses.

Conflict of interest statement.- The authors declare that this paper has no conflict of interest and none of the authors has any other financial or personal relationships that could inappropriately influence or bias the content of the paper.

\section{REFERENCES}

Bullone M., De Lagarde M., Vargas A. \& Lavoie J.P. 2015. Serum surfactant protein D and haptoglobin as potential biomarkers for inflammatory airway disease in horses. J. Vet. Intern. Med. 29(6):1707-1711. <http://dx.doi.org/10.1111/jvim.13602> <PMid:26289543>

Christoffersen M., Baagoe C.D., Jacobsen S., Bojesen A.M., Petersen M.R. \& Lehn-Jensen H. 2010. Evaluation of the systemic acute phase response and endometrial gene expression of serum amyloid A and pro- and anti-inflammatory cytokines in mares with experimentally induced endometritis. Vet. Immunol. Immunopathol. 138(1/2):95-105. <http://dx.doi.org/10.1016/j.vetimm.2010.07.011><PMid:20728224>

Couëtil L.L., Cardwell J.M., Gerber V., Lavoie J.P., Léguillette R. \& Richard E.A. 2016. Inflammatory airway disease of horses - revised consensus statement.J. Vet. Intern. Med. 30(2):503-515. <http://dx.doi.org/10.1111/ jvim.13824><PMid:26806374>

Couëtil L.L., Hoffman A.M., Hodgson J., Buechner-Maxwell V., Viel L., Wood J.L. \& Lavoie J.P. 2007. Inflammatory airway disease of horses. J. Vet. Intern. Med. 21:356-361.

Coutinho da Silva M.A., Canisso I.F., MacPherson M.L., Johnson A.E. \& Divers T.J. 2014. Serum amyloid A concentration in healthy periparturient mares and mares with ascending placentitis. Equine Vet. J. 45(5):619-624 <http://dx.doi.org/10.1111/evj.12034><PMid:23432049>

Crisman M.V., Scarratt W.K. \& Zimmerman K.L. 2008. Blood proteins and inflammation in the horse. Vet. Clin. N. Am., Equine Pract. 24(2):285-297. <http://dx.doi.org/10.1016/j.cveq.2008.03.004><PMid:18652956>

Cywinska A., Witkowski L., Szarska E., Schollenberger A. \& Winnicka A. 2013. Serum amyloid A (SAA) concentration after training sessions in Arabian race and endurance horses. BMC Vet. Res. 9:91. <http://dx.doi.org/10.1186/1746-6148-9-91><PMid:23634727>

Duggan V.E., Holyoak G.R., MacAllister C.G., Cooper S.R. \& Confer A.W. 2008 Amyloid A in equine colostrum and early milk. Vet. Immunol. Immunopathol. 121(1/2):150-155. <http://dx.doi.org/10.1016/j.vetimm.2007.06.030> $<$ PMid:17681383> 
Hobo S., Niwa H. \& Anzai T. 2007. Evaluation of serum amyloid A and surfactant protein $\mathrm{D}$ in sera for identification of the clinical condition of horses with bacterial pneumonia. J. Vet. Med. Sci. 69(8):827-830. <http://dx.doi.org/10.1292/jvms.69.827><PMid:17827889>

Hultén C. \& Demmers S. 2002. Serum amyloid A (SAA) as an aid in the management of infectious disease in the foal: comparison with total leucocyte count, neutrophil count and fibrinogen. Equine Vet. J. 34(7):693-698. <http://dx.doi.org/10.2746/042516402776250360><PMid:12455840>

Hultén C., Sandgren B., Skiöldebrand E., Klingeborn B., Marhaug G. \& Forsberg M. 1999. The acute phase protein serum amyloid A (SAA) as an inflammatory marker in equine influenza virus infection. Acta Vet. Scand. 40(4):323-333. <PMid: 10918902>

Jacobsen S. \& Andersen P.H. 2007. The acute phase protein serum amyloid A (SAA) as a marker of inflammation in horses. Equine Vet. Educ. 19(1):3846. <http://dx.doi.org/10.2746/095777307X177235>

Jacobsen S., Thomsen M.H. \& Nanni S. 2006a. Concentrations of serum amyloid A in serum and synovial fluid from healthy horses and horses with joint disease. Am. J. Vet. Res. 67(10):1738-1742.<http://dx.doi.org/ 10.2460/ ajvr.67.10.1738><PMid:17014325>

Jacobsen S, Niewold T.A., Halling-Thomsen M., Nanni S., Olsen E., Lindegaard C. \& Andersen P.H. 2006b. Serum amyloid A isoforms in serum and synovial fluid in horses with lipopolysaccharide-induced arthritis. Vet. Immunol. Immunopathol. 110(3/4):325-330. <http://dx.doi.org/10.1016/j. vetimm.2005.10.012><PMid:16337010>

Lavoie-Lamoureux A, Leclere M., Lemos K., Wagner B. \& Lavoie J.P. 2012. Markers of systemic inflammation in horses with heaves. J. Vet. Intern. Med. 26(6):1419-1426. <http://dx.doi.org/10.1111/j.1939-1676.2012.00993.x> $<$ PMid:22925172>

Leclere M., Lavoie-Lamoureux A. \& Lavoie J.P. 2015. Acute phase proteins in racehorses with inflammatory airway disease. J. Vet. Intern. Med. 29(3):940945. <http://dx.doi.org/10.1111/jvim.12587><PMid:25857218>

McDonald T.L., Larson M.A., Mack D.R. \& Weber A. 2001. Elevated extrahepatic expression and secretion of mammary-associated serum amyloid A3 (M-SAA3) into colostrum. Vet. Immunol. Immunopathol. 83(3/4):203-211. <http://dx.doi.org/10.1016/s0165-2427(01)00380-4><PMid:11730930>

O’Hara R., Murphy E.P., Whitehead A.S., FitzGerald O. \& Bresnihan B. 2004. Local expression of the serum amyloid A and formyl peptide receptor-like 1 genes in synovial tissue is associated with matrix metalloproteinase production in patients with inflammatory arthritis. Arthritis Rheumatol. 50(6):1788-1799. <http://dx.doi.org/10.1002/art.20301><PMid:15188355>
Passamonti F., Vardi D.M., Stefanetti V., Marenzoni M.L., Prato S., Cévese P., Coletti M., Pepe M., Casagrande Proietti P. \& Olea-Popelka F. 2015. Rhodococcus equi pneumonia in foals: aAn assessment of the early diagnostic value of serum amyloid $\mathrm{A}$ and plasma fibrinogen concentrations in equine clinical practice. Vet J. 203 (2): 211-218. <http://dx.doi.org/10.1016/j. tvjl.2014.08.033><PMid:25555337>

Turło A., Cywinska A., Czopowicz M., Witkowski L., Szarska E. \& Winnicka A. 2015a. Post-exercise dynamics of serum amyloid A blood concentration in thoroughbred horses classified as injured and non-injured after the race. Res. Vet. Sci. 100:223-225. <http://dx.doi.org/10.1016/j.rvsc.2015.04.008> <PMid:25933933>

Turło A., Cywińska A., Czopowicz M., Witkowski L., Niedźwiedź A., Słowikowska M., Borowicz H., Jaśkiewicz A. \& Winnicka A. 2015b. The effect of different types of musculoskeletal injuries on blood concentration of serum amyloid A in thoroughbred racehorses. Plos One 10(10):1-10. <http://dx.doi.org/10.1371/journal.pone.0140673><PMid:26466121>

Uhlar C.M. \& Whitehead A.S. 1999. Serum amyloid A, the major vertebrate acute-phase reactant. Eur. J. Biochem. 265(2):501-523. <http://dx.doi.org/10.1046/j.1432-1327.1999.00657.x><PMid:10504381>

Upragarin N., Landman W.J., Gaastra W. \& Gruys E. 2005. Extrahepatic production of acute phase serum amyloid A. Histol. Histopathol. 20(4):1295-1307. <http://dx.doi.org/10.14670/HH-20.1295><PMid:16136510>

Urieli-Shoval S., Cohen P., Eisenberg S. \& Matzner Y. 1998. Widespread expression of serum amyloid $\mathrm{A}$ in histologically normal human tissues: predominant localization to the epithelium. J. Histochem. Cytochem. 46(12):1377-1384. <http://dx.doi.org/10.1177/002215549804601206> <PMid:9815279>

Viner M., Mazan M., Bedenice D., Mapes S. \& Pusterla N. 2017. Comparison of serum amyloid $\mathrm{A}$ in horses with infectious and non-infectious respiratory diseases. J. Equine Vet. Sci. 49:11-13. <http://dx.doi.org/10.1016/j. jevs.2016.09.005>

Viscardi V., Lopes A.C.G., Beling J.C.F., Gioia G.V., Torres Filhos R.A., Lessa D.A.B. \& Alencar N.X. 2015. Effects of single and duplicate infusions of $250 \mathrm{~mL}$ of saline solution in the cytological evaluation of bronchoalveolar lavage in equines. Braz. J. Vet. Med. 37(1):33-35.

Wysocka B. \& Kluciński W. 2015. Cytological evaluation of tracheal aspirate and broncho-alveolar lavage fluid in comparison to endoscopic assessment of lower airways in horses with recurrent airways obstruction or inflammatory airway disease. Pol. J. Vet. Sci. 18(3):587-597.<http://dx.doi.org/10.1515/ pjvs-2015-0076><PMid:26618592> 